ETO: 811.511.141:81'243

811.163.42:81'243

ORIGINAL SCIENTIFIC PAPER

$811.521: 81^{\prime} 243$

$81 ' 232$

DOI: $10.19090 /$ hk.2020.4.90-108

BORSOS Levente

Külgazdasági és Külügyminisztérium Diplomáciai Akadémia

Budapest, Magyarország

leventeborsos@yahoo.es

KRUZSLICZ Tamás

Ljubljanai Egyetem

Általános és Összehasonlító Nyelvészeti Tanszék

Ljubljana, Szlovénia

kruzslicztamas@gmail.com

OSZKÓ Beatrix

Újvidéki Egyetem, Bölcsészettudományi Kar

Magyar Nyelv és Irodalom Tanszék

Újvidék, Szerbia

Nyelvtudományi Intézet

Budapest, Magyarország

oszkobea@gmail.com

\title{
A KOLLABORATIIV ONLINE NYELVTANULÁS LEHETŐSÉGEI ÉS TANULSÁGAI KÉT MAGYAR MINT IDEGEN NYELVI PROJEKT ALAPJÁN
} Horvát-magyar-japán közelitések

Collaborative online language learning: Potentials and lessons learnt based on two Hungarian as a foreign language projects

Croatian - Hungarian - Japanese convergences

Mogućnosti i pouke kolaborativne onlajn nastave jezika na osnovu dva istraživačka projekta mađarskog jezika kao stranog Hrvatsko-mađarsko-japanski primer

A dolgozat egy magyar mint idegen nyelv oktatásához kapcsolódó kutatás eredményeiből mutat be részleteket. Magyar tanárjelöltek, japán és horvát nyelvtanulók voltak a résztvevői a budapesti, oszakai és eszéki egyetemeken zajló két projektnek, melyek középpontjában az 
interkulturális kommunikatív kompetencia és az IKT-eszközök használata állt. A kommunikációs felületet közösségi oldalak biztosították (LINE, illetve Facebook). A számítógépen és telefonon egyaránt megjeleníthető tematikus feladatokat a tanárjelöltek készítették, melyeket a nyelvtanulók jellemzően páros vagy csoportos munka során oldottak meg. A projektek utolsó eleme egy a résztvevők által kitöltött kérdőíves felmérés volt. Ennek eredményei alapján számolunk be arról, mit tartottak hasznosnak a résztvevők, illetve mi jelentett nehézséget számukra. Az előzetes elvárásoknak megfelelően a kultúraközvetítés, a valós kommunikáció a pozitívumok között szerepelt, ahogy az IKT-eszközök használatában szerzett gyakorlat is. A két nyelvtanuló csoport eltérő mértékben jelölte meg a nehézséget okozó tényezőket. A nemzetközi tapasztalatokkal egybevágóan kutatásunk eredményei is azt bizonyítják, hogy a tanári irányítás elengedhetetlen eleme e projekteknek, azzal viszont sikeres és hatékony színfolt lehet a nyelvtanítás és -tanulás palettáján.

Kulcsszavak: interkulturális kommunikatív kompetencia, magyar mint idegen nyelv, posztkommunikatív nyelvoktatás, valós kommunikáció, web 2.0

\section{Bevezetés}

A napjainkat uraló járványhelyzet adja aktualitását annak, hogy bemutassunk két párhuzamos projektet, amelyek egyik meghatározó tényezője már 2016ban és 2017-ben is a távolság és a személyes jelenlét hiányának leküzdése volt.

A nyelvtanításban a nyelv tárgya és egyben eszköze is a tanulási folyamatnak. Az egyetemi nyelvoktatásban - mind nyelvszakos, mind nyelvtanári szakos hallgatók esetében - mégis gyakran háttérbe szorul a valódi kommunikációs készség fejlesztése. Emellett sokszor a mindennapi kultúra közvetítésére, az interkulturális kommunikatív kompetencia fejlesztésére, valamint az ezzel kapcsolatos nyelvhasználat közvetítésére is kevesebb figyelem irányul (vö. Holló 2016).

A nyelvtanárképzésben a fent említett problémákat fokozza, hogy a hallgatóknak kevés lehetőségük van a valós kommunikáció közvetítésének kipróbálására. A XXI. századi posztkommunikatív nyelvoktatás kihívása, hogy a nyelvet saját kontextusában, valódi kommunikációs helyzeteket teremtve, problémamegoldó (nem tantermi) célból készített feladatok révén közvetítse (vö. Ellis 2003; ITLR 2011; Illés-Akcan 2017). Ennek a helyzetnek felel meg a digitális kommunikációra épülő projektalapú nyelvoktatás - erre mutatunk példát az alábbiakban, abban bízva, hogy a kutatás során szerzett és itt megosztott tapasztalataink más hasonló vállalkozások számára is hasznosak lehetnek.

A következőkben két web 2.0-s környezetben zajló, nemzetközi tanulásitanítási projektet és a rájuk épülő kutatás eredményeit mutatjuk be. A magyarul tanuló japán és horvát nyelvtanulók, valamint magyar anyanyelvü magyar 
mint idegennyelv-tanár szakos hallgatók részvételével megvalósult projektek ${ }^{1}$ az információs és kommunikációs technológia (IKT) segítségével zajlottak. Mindkét projekt elsődleges kommunikációs csatornái a közösségi oldalak voltak.

A projektek elsődleges célja a célnyelvi környezettől távol zajló nyelvtanulás segítése volt, azaz hogy közösségi oldalak bevonásával olyan felületet biztosítsanak, amelyen a magyarul tanuló hallgatók valós kommunikációs környezetben gyakorolhatják a célnyelvet annak anyanyelvi beszélöivel. Ugyanakkor a leendő magyar mint idegennyelv-tanárok is lehetőséget kaptak az általuk készített online feladatok kipróbálására és a közvetlen kommunikációra a nyelvtanulókkal. Feltételezésünk az volt, hogy egy ilyen projekt segíti a kommunikációs kompetencia fejlesztését, különös tekintettel az interkulturális kommunikatív kompetenciára (IKK), emellett motiválja a nyelvtanulókat spontán célnyelvi kommunikáció megvalósítására is. A tanárjelöltek számára a projekt lehetőséget biztosított a tanári kommunikáció fejlesztésére, a célnyelvi közvetítőnyelv használatának gyakorlására, az IKK fejlesztésére, miközben egyéb tanári kompetenciáikat is fejlesztette. Az IKT-eszközök bevonása a tanulási folyamatba a természetes kommunikációs közeg biztosítása mellett további motivációs forrásként is szolgált. A Japánban rendkívül elterjedt IKT a hallgatók mindennapi életének is szerves része (W1), így feltételeztük azt is, ezek tanórai alkalmazása pozitív hatással lesz a célnyelvi kommunikációra való hajlandóságuk támogatásában (Borsos-Kruzslicz 2019, 92-93). A horvát hallgatók esetében az IKT tanórai használata nem volt a mindennapi gyakorlat része, de mint kutatásunkból kiderült, magánéletükben meghatározó a közösségi platformok használata. A kulturális távolság tekintetében azonban a japánnal összevetve kisebb kulturális különbség áll fenn a horvát és a magyar kultúra között.

A projektek középpontjában az interakció megteremtése és az interkulturális tartalmak közvetítése állt. A következőkben bemutatjuk, milyen előnyei és hátrányai lehetnek a digitális kommunikációra épülő, projektalapú nyelvoktatásnak, valamint azt is, mennyiben voltak megvalósíthatóak a kitüzött célok.

\section{Elméleti háttér}

Van Ek (1986) elkülöníti a szociokulturális kompetenciát (sociocultural competence) és a szociális kompetenciát (social competence). Elöbbi alatt a különböző kultúrákban való müködés képességét, utóbbin a másokkal való

\footnotetext{
${ }^{1}$ A japán projektről bővebben: Borsos-Kruzslicz 2017.
} 
kommunikáció során a különböző társadalmi szokások ismeretét, a bizalom, az empátia és a motiváció képességét érti. Ez a két kompetencia adja az IKK alapját, amely Beneke $(2000,109)$ meghatározásában ,a saját kulturális háttér feldolgozásának képességét jelenti a másokkal folytatott interakció során" ${ }^{2}$.

Az IKK - mint minden kulcskompetencia - attitüdökből, ismeretanyagból és képességekből épül fel (OECD 2005, 4). Az attitüdök része a kíváncsiság, a nyitottság, a készség más kultúráknak, illetve a saját kultúrának az elöítéletmentes megismerésére. Az ismeretek a beszélő saját, illetve a beszélőpartnerének országára jellemző társadalmi, kommunikációs gyakorlatokról alkotott tudását tartalmazza. A készségek a különböző kultúrák képviselői közötti interakció értelmezésének és a helyzethez való adekvát kapcsolódásnak a képességét jelentik, illetve a kulturális tudatosságot és a kulturális jelenségekkel szembeni kritikus, elemző hozzáállást (Byram 1997). Az idegen nyelvek tanulása és tanítása során megfelelő kulturális kontextus esetén a nyelvtanulók érzékenysége párhuzamosan fejlődik a nyelvhez (nyelvtan, szintaxis, szókincs) és a nyelvhez kapcsolódó kultúrához (mind a civilizációs, mind a mindennapi kultúra értelmében - vö. Szili 2005, 48): „A kommunikatív kompetencia megfelelő elsajátítása során a diákok képesek lesznek felülemelkedni a fellépő kulturális alkalmazkodási nehézségeken, és (remény szerint) közben a motivációjuk is növekszik saját maguk és mások kulturális megismerésére" (Peck et al. 2007, 21-22).

Kutatási projektünk a nemzetközi szakirodalomban a kollaboratív online tanulásként (O’Dowd-Lewis 2016, 3) megjelenő tanításmódszertani koncepcióhoz illeszkedett. Ez egy olyan tanulási forma, amely tanári irányítással különböző kulturális háttérrel rendelkező vagy eltérő földrajzi helyen lévő csoportok részvételével az online térben zajlik interkulturális interakciók és együttmúködés formájában (Orsini-Jones-Lee 2016, 2).

\section{Az IKT és az idegen nyelvi kommunikáció}

A digitális kompetencia - az idegen nyelvi kommunikációhoz hasonlóan része annak az Európai Parlament és az Európai Tanács által 2006-ban meghatározott nyolc kulcskompetenciának, amelyek folyamatos fejlesztése elengedhetetlen mind az intézményes oktatás különböző színterein, mind az egyéni, élethosszig tartó tanulás során (Európai Parlament-Európai Tanács, 2006).

\footnotetext{
${ }^{2}$ A cikkben szereplő, nem magyar nyelvű szakirodalomból származó idézetek a szerzők saját fordításai.
} 
A 2020-as év bizonyította, hogy a digitális tér nemcsak lehetséges, hanem olykor szükséges és kizárólagos terepe is az oktatásnak. Ebben a helyzetben - hasonlóan a nem célnyelvi környezetben zajló nyelvtanuláshoz - az IKT nemcsak a szüken vett tanítás eszköze, hanem kommunikációs csatornaként az idegen nyelvi kommunikáció és a kultúraközvetítés első számú színterét jelentheti.

A digitális technológia pedagógiai használatáról az Innovative Teaching and Learning kutatócsoport (ITLR) széles körü vizsgálatot végzett. Eredményeik szerint az IKT-környezetben megvalósuló tanulási folyamat támogatja a XXI. századi ember számára fontos készségeket: a tudásépítést, a kreatív eszközhasználatot, az önszabályozást, a valódi problémák megoldását és az együttmüködés készségét (ITLR 2011,2). Ezeknek a készségeknek a fejlesztése a projektjeinkben is fontos szerepet kapott. A tudásépítést a kulturális ismeretek megszerzése, a kreatív eszközhasználatot az okostelefonok sokrétủ alkalmazása (fotók, videók készítése, tanulást segítő oldalak használata stb.), az önszabályozást az egyéni tervezés támogatta. A projektek biztosították a tanórai kereteken túllépő idegen nyelvi kommunikációs helyzeteket a résztvevők között. Kulcsszerepet kapott a kollaboratív interakció és az együttmüködés képességének fejlesztése is. Tapasztalataink is alátámasztották, hogy az IKT nem pusztán lehetővé teszi az idegen nyelvi kommunikációt, hanem hozzájárul az autonóm nyelvtanulóvá váláshoz, és támogatja a kommunikatív kompetenciához szükséges ismeretek, készségek és attitűdök kialakulását is.

\section{A projektek}

A japán-magyar projekt 2016. november-decemberben zajlott. Részben az itt szerzett tapasztalatokat felhasználva került sor a horvát-magyar projektre 2018 februárja és júniusa között. A projekt japán résztvevői az Oszakai Egyetem, a horvát résztvevők pedig az eszéki Josip Juraj Strossmayer Egyetem magyar szakos $^{3}$ hallgatói voltak. Magyar részről mindkét projekt esetében az ELTE magyar mint idegennyelv-tanári mesterképzésének másodéves hallgatói vettek részt az IKT-eszközök a magyar mint idegen nyelv tanításában kurzus keretében.

Mindkét projekt közös jellemzője volt a részt vevő felek közötti fizikai távolság, amelyet az IKT segítségével hidaltunk át. Ugyancsak közös pont volt az IKK fejlesztésének középpontba állítása. Ez egyrészt a kulturális ismeretanyag kölcsönös átadásában (kultúraközvetítés), másrészt a közösen végzett tevékenység során létrejövő interakcióban és ezek attitüdformáló hatásában

\footnotetext{
${ }^{3}$ A magyar szakpárosításban tanulható, a másik szak horvát, angol vagy történelem lehet.
} 
valósult meg. A fő célok és eszközök azonossága mellett eltérések is voltak - részben az első projekt tanulságaiból kiindulva, részben a helyi adottságok miatt. A részletek az 1. táblázatban olvashatók.

\begin{tabular}{|c|c|c|}
\hline & Oszaka & Eszék \\
\hline $\begin{array}{l}\text { A projekt } \\
\text { idötartama }\end{array}$ & 2016. november-december & 2018. február-június \\
\hline $\begin{array}{l}\text { Külföldi } \\
\text { résztvevök }\end{array}$ & $\begin{array}{l}\text { az Oszakai Egyetem másod-, } \\
\text { harmad- és negyedéves } \\
\text { magyar szakos hallgatói } \\
3 \text { csoport } \\
39 \text { fö }\end{array}$ & $\begin{array}{l}\text { a J. J. Strossmayer Egyetem } \\
\text { másod- és harmadéves } \\
\text { hallgatói } \\
2 \text { csoport } \\
18+20 \text { fö } \\
\text { (A projektben mindkettő, } \\
\text { de a kutatásban csak az első } \\
\text { csoport vett részt.) }\end{array}$ \\
\hline \multirow[t]{2}{*}{$\begin{array}{l}\text { Magyar } \\
\text { résztvevök }\end{array}$} & \multicolumn{2}{|c|}{$\begin{array}{l}\text { ELTE MID tanári MA másodéves hallgatók } \\
\text { IKT-eszközök a magyar mint idegen nyelv tanitásában kurzus }\end{array}$} \\
\hline & 3 fó & 16 fö \\
\hline Témakörök & $\begin{array}{c}\text { A Pál utcai fiúk } \\
\text { (csak a másodévesekkel) } \\
\text { Decemberi ünnepek }\end{array}$ & $\begin{array}{c}\text { A pesti egyetemisták élete } \\
\text { Horvát-magyar kulturális } \\
\text { kapcsolatok }\end{array}$ \\
\hline Felület & $\mathrm{LINE}^{4}$ & Facebook \\
\hline $\begin{array}{l}\text { Vizsgálati } \\
\text { módszerek }\end{array}$ & \multicolumn{2}{|c|}{$\begin{array}{l}2 \text { online kérdőív, közvetlen megfigyelés, személyes } \\
\text { szóbeli értékelés }\end{array}$} \\
\hline Kiemelt területek & \multicolumn{2}{|c|}{ IKK és IKT } \\
\hline
\end{tabular}

1. táblázat. Az oszakai és az eszéki hallgatókkal zajlott projektek összehasonlítása

A projektek mindkét esetben hasonló módon zajlottak. A magyar hallgatók a nyelvtanulói csoportok és a projekt céljainak megismerése után önállóan dolgozták ki feladataikat, amelyeket a kurzus vezetőjével közösen véglegesítettek. A feladatokat ezután a külföldi egyetemek oktatói véleményezték, majd a magyar diákok feltöltötték ezeket a projekt során használt online felületeken (LINE/ Facebook) létrehozott zárt csoportokba. A japán projekt esetében a feladatok tantermi megoldása során a lektor követte a tanárjelöltektől kapott instrukciókat,

\footnotetext{
${ }^{4}$ https://line.me/en/ (2020. dec. 11.)
} 
hogy a magyar hallgatók minél pontosabb visszajelzést kaphassanak az általuk készített tananyagokról. A projektben felhasznált közösségi oldalak lehetővé tették, hogy a magyar hallgatók folyamatosan figyelemmel kísérjék a feladatok megoldását és biztosították a közvetlen interakciót is a résztvevők között. Az órák után a lektorok beszámoltak tapasztalataikról magyar kollégájuknak, aki később ezeket a magyar hallgatókkal is megvitatta.

A projektek lezárultával a résztvevők kérdőívet töltöttek ki, ebben reflektáltak a feladatokra, azok hatékonyságára és az elért eredményekre. A felmérés a Google-kérdőív alkalmazással történt, a nyelvtanulók a kérdéseket célnyelven és anyanyelvükön is olvashatták. A kérdések többsége feleletválasztós volt, kisebb részükre szabad szöveges választ vártunk. A projektek értékelésekor felhasználtuk a feladatkészítési és -megoldási folyamat során szerzett tapasztalatokat is. Jelen cikkben a kutatási eredmények közül az előzetes hallgatói elvárásokat, illetve a feladatok megoldása során felmerülő nehézségek bemutatását emeljük ki, majd a közös tanulási folyamat során fejlesztett idegen nyelvi kompetenciához kapcsolódó területeket tekintjük át a nyelvtanuló hallgatók perspektívájából, az általuk megfogalmazott reflexiók segítségével. Ezzel a három kiemelt szemponttal a tervezés, a megvalósulási folyamat és az eredmények is megjelennek - átfogó képet adva egy kollaboratív online tanulási projekt lehetséges lefolyásáról és tanulságairól.

\section{A résztvevökröl}

Az oszakai projektben részt vevő japán hallgatókra jellemző az idegen nyelvek és kultúrák iránti nyitottság és érdeklődés, amit az általuk választott idegen nyelv szakos tanulmányokon túl a kérdőívre adott válaszaik is megerösítettek. Az idegen nyelvek és kultúrák iránti pozitív attitűdöt mutatja a válaszadók által tanult idegen nyelvek száma és sokszínüsége: a magyar nyelvet is beleszámítva a résztvevők 3-4 idegen nyelvet beszéltek, illetve tanultak, ami átlagon felülinek mondható a teljes japán lakosság adataihoz képest (AppleDa Silva-Fellner 2013. xi. o.). A magyar résztvevők egyike sem beszélt japánul, ami részben segítette a projekt céljainak elérését - kizárva a nyelvtanulók anyanyelvén történő kommunikációt -, ugyanakkor jelzi, hogy a magyar hallgatók kevés ismerettel rendelkeztek a tanulók anyanyelvéről és kulturális hátteréról, ami bizonyos esetekben nehezítette a munkát.

Az eszéki hallgatók is nyitottak voltak, érdeklődéssel várták az új projekt adta lehetőségeket. A földrajzi adottságoknak köszönhetően számukra a magyar anyanyelvüekkel való találkozás megoldható lenne. Eszék a Horvátország észak- 
keleti területén található magyar kisebbség központja - még ha a városban a magyar ajkú lakosság aránya elenyésző is -, és Magyarország földrajzi közelsége is könnyebben elérhetővé teszi a célnyelvi környezetet. A tapasztalatok szerint a kedvező helyzet ellenére a diákok külső segítség nélkül nem keresik a kommunikációs lehetőségeket magyar anyanyelvűekkel. Az idegen nyelvek ismerete a horvát hallgatók körében eltérő mértékü, minimális angoltudással mindenki rendelkezik, de előfordul 3-4 idegen nyelv ismerete is körükben. Középiskolában mindenki tanul legalább két idegen nyelvet (ez jellemzően az angol és a német), az egyetemisták idegennyelv-tudása sok esetben függ a szakpárjuktól is. A horvát relációban is elmondható, hogy a magyar hallgatók egyike sem beszélt horvátul, de ennek nem volt számottevő jelentősége, hiszen közöttük és a nyelvtanulók között - a közös kulturális areának köszönhetően - nincs jelentős kulturális különbség.

Itt említjük meg, hogy bár a horvát tanulók két csoportja is részt vett a projektben, a kutatásban csak a másodévesek eredményeit vettük figyelembe, akik - a japán hallgatókhoz hasonlóan - tanári felügyelettel, a feladatokat az órai munkába beépítve dolgoztak. A harmadévesek a részletes kezdő eligazítás után nem álltak intenzív tanári felügyelet alatt. A feladatok mindegyike alkalmas volt az önálló egyéni vagy csoportos tanulásra, ennek ellenére ebböl az évfolyamból csak kevesen vállalkoztak feladatmegoldásra, így visszajelzéseikből nem nyerhettünk szignifikáns adatokat a kutatás számára, azokat nem használtuk fel.

\section{Eredmények és tanulságok Elözetes elvárások}

A projekt fő pedagógiai célja a tanárjelöltek és a nyelvtanulók IKK-jának fejlesztése volt az IKT segítségével. A nyelvtanulók oldaláról jól mutatják a célkitüzés relevanciáját a japán hallgatóknak a projekt megkezdése előtti előzetes várakozásai: a 31 résztvevő 58,1\%-a remélt kommunikációs lehetőséget magyar anyanyelvúekkel, és ugyanennyien számítottak új, kulturális ismeretek tanulására. Ezek az adatok a horvát hallgatók körében a következők: kommunikációs lehetőség: $63,6 \%$, játékos tanulás: $59,1 \%$, a kulturális ismeretek bővülése: $40,9 \% .{ }^{5}$ (Lásd 1. ábra.)

A magyar tanárjelöltek kevésbé érdeklődtek az új kulturális ismeretek iránt, inkább szakmai kompetenciájuk fejlődését remélték a közös munkától.

\footnotetext{
${ }^{5}$ A válaszadók több választ is megjelölhettek.
} 
Elvárásaik között egyhangúlag említették a kapcsolati lehetőséget a magyart idegen nyelvként tanuló diákokkal, új módszertani ismeretek megszerzésének lehetőségét a MID tanításáról, de az IKT-s lehetőségek nyelvórai alkalmazását is többen jelölték meg a kulturális ismereteik bővítésénél, amely csupán harmaduknál szerepelt.

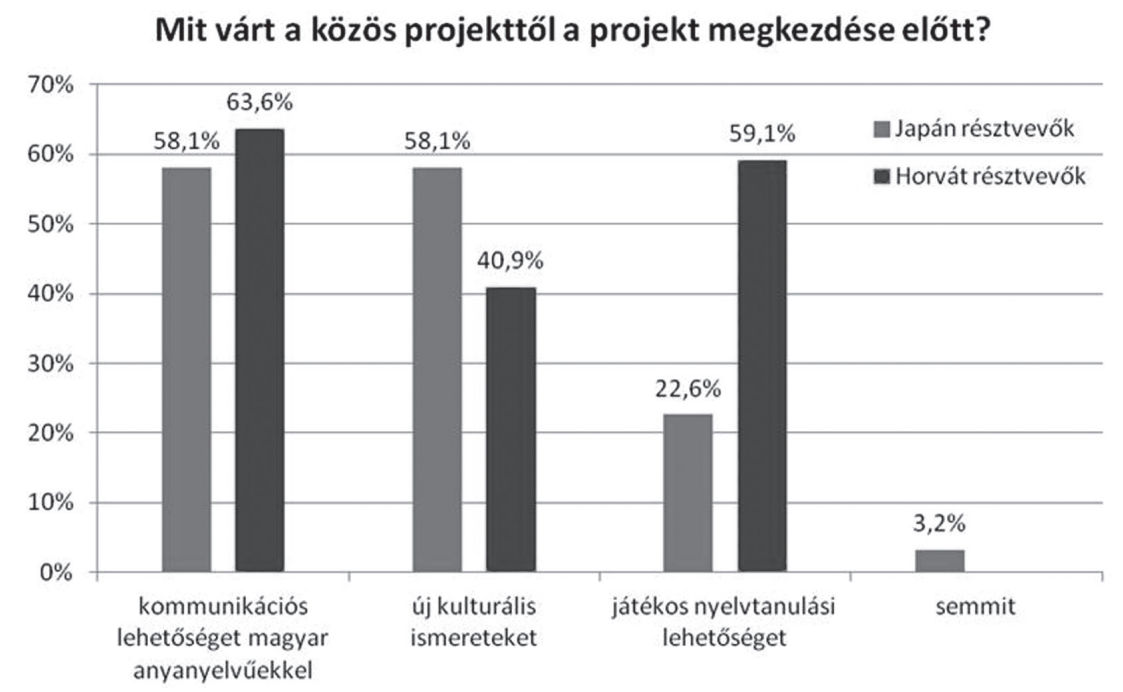

1. ábra. A Mit várt a közös projekttől a projekt megkezdése elött? kérdésre adott nyelvtanulói válaszok

\section{A feladatokról}

A projektben tartalmilag a tudásközvetítés szintjén is megjelentek a kulturális ismeretek. A részt vevő felek közötti kulturális közvetítés kölcsönös volt, nemcsak a tanárjelölteknek, hanem több feladatban a nyelvtanulóknak is reflektálniuk kellett saját kultúrájukra (Mikulás Japánban, Szilveszterezési szokások Japánban, A Mlinar Magyarországon, Kirándulás Horvátországban). A projekt minden feladatának középpontjában a diákok interkulturális kompetenciájának fejlesztése állt. A magyar hallgatók szabadon dönthettek arról, milyen eszközökkel próbálják elérni ezt a célt, és hogyan dolgozzák fel a témákat. Az elkészült feladatok ilyen szempontból is változatosak voltak, összesen 13 különböző alkalmazás felhasználásával készültek az egységesen, a közösen használt közösségimédia-felületekre kerülő feladatok. Az egyes témáknál megjelentek a beszédkészséget fejlesztő, valós körülményekre épülő szituációs játékok, 
amelyeket a projektben résztvevők videón rögzítettek (például a vásárlás a karácsonyi vásárban feladat valós, a budapesti vásárban videóra felvett input alapján; a horvát hallgatók kedvenc egyetemi helyeinek videós bemutatása), az olvasott szöveget feldolgozó, a közös kollaborációt és azon keresztül a célnyelvi kommunikációt is fejlesztő feladatok (például közös, horvát-magyar történelmi hösök bemutatása, A Pál utcai fiúk egyes kiválasztott kulcsjeleneteinek nonverbális bemutatása egy fotón és annak képregényszerü megszövegezése), illetve az íráskészség fejlesztésére is alkalmas elemek (például újévi jókívánságok írása egymásnak a közösségi oldalakon és válaszadás ezekre, utazási ajánló készítése célnyelven egy utazási ajánlatokat közzétevő oldalon).

A produktív készségekre helyezett hangsúlynak köszönhetően minden diák a saját tudásának megfelelő szinten vehetett részt a projektben, ez lehetővé tette a szintbeli különbségek kezelését, illetve az egyéni differenciálást is. Különösen azok a tevékenységek arattak nagy tetszést, amelyek az IKT-eszközökben rejlö lehetőségeket mind a produktív készségek fejlesztésének, mind az interkulturális ismeretek közvetítésének szolgálatába tudták állítani (vö. Piros 2006, 94). Az első kézből kapott interkulturális információk, az interaktív jelleg és ehhez (is) kapcsolódóan az IKT-s lehetőségek hatékony kihasználása mellett a kooperatív munkaformák és a tanulói autonómia elősegítése mind motiváló hatással bírtak. Ezek sikeres kombinációja jelent meg a visszajelzések alapján a japán hallgatóknál a decemberi ünnepek témakör feldolgozásában, amikor a nyelvtanulók, a már említett karácsonyi vásáros szituációt rögzítették videóra. Talán a feladat motiváló erejének is volt köszönhető, hogy a feladatmegoldások színvonalát illetően is ez volt a projekt egyik legjobban sikerült eleme annak ellenére is, hogy kezdetben szokatlannak és kínosnak érezték, hogy magukról készítsenek videót - föleg azért, mert ezeket a többi diák és a magyar hallgatók is láthatták a közös LINE-csoportban.

A japán tapasztalatok alapján a videó készítése a horvát hallgatóknál már a kezdetektől fogva (enyhítve a „szereplési” szituáció izgalmát) nem egyéni, hanem csoportos feladatként jelent meg. Talán ez is hozzájárult az említetteken túl, hogy esetükben is a legsikeresebb feladatnak ítélhetjük mind a kivitelezés, mind pedig a kompetenciák fejlesztése szempontjából az egyetemet, az egyetemistákat és az Eszék egy-egy nevezetességét bemutató felvételeket. Itt is érvényesülhetett a differenciálás az egyéni adottságokhoz igazodva: volt, aki szívesen szerepelt, a félénkebbek pedig választhattak nekik alkalmasabb feladatrészt a videó készítésekor. 


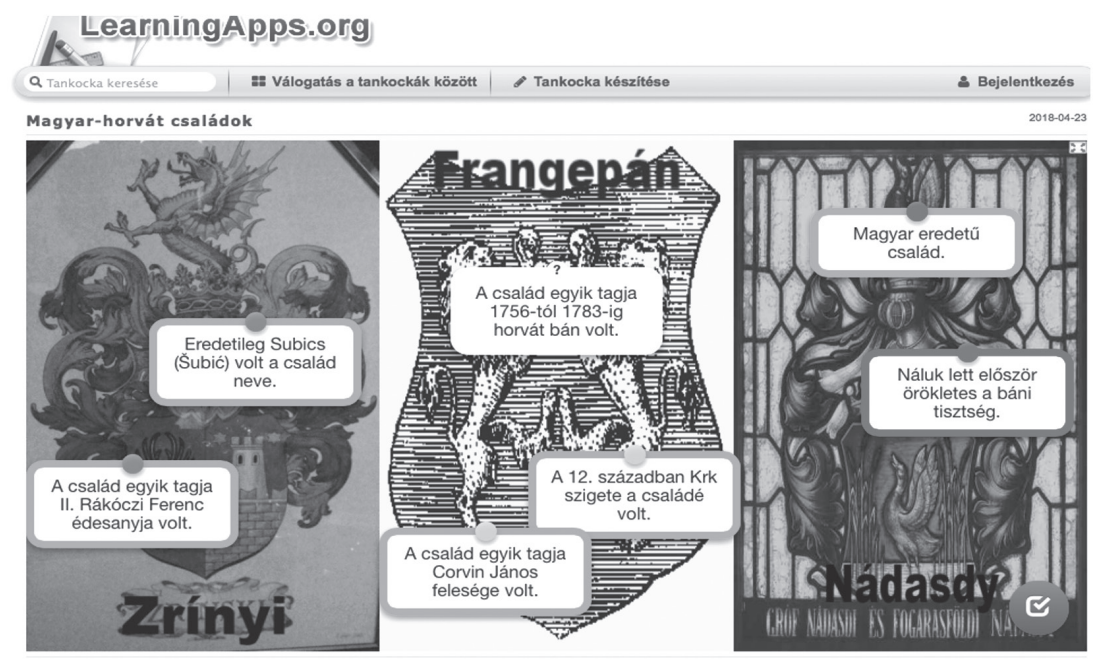

2. ábra. A magyar hallgatók által készített feladat a horvát-magyar nemesi családokról a LearningApps felületén

\section{Amiben segitett a projekt}

Mindkét nyelvtanuló csoport visszajelzésében hangsúlyosan szerepelnek a magyar kultúráról szerzett új ismeretek, vetekedve a szókincs bővülésével. A feldolgozott témák újszerüségével és a hagyományos tananyagoktól való eltéréssel magyarázható a szókészlet jelentős gyarapodása mindkét nyelvtanulói csoport számára - bár ezt a nehézségek között is feltüntették. A kulturális ismeretek közvetítése óhatatlanul sok új szó bevezetésével jár, ráadásul ezek azonnali, gyakorlati alkalmazását is megkövetelték a feladatok. A projekt gyakorlatai kontextust teremtettek a szókincs kommunikációba helyezéséhez. Segítette a szótanulást, hogy az új lexikális elemeket kommunikáció során is rögzítették. A magyar tanárjelöltek is kiemelték, hogy nehéz volt a diákok tudásszintjének megfelelő szókincs használata. A horvát hallgatók bevallása szerint az írott szöveghez kapcsolódó készségeik fejlödtek leginkább: az olvasott szöveg értése és az íráskészség, ezzel szemben a japán csoportoknál ezek nem jelentős tényezők (vö. 3. ábra). A táblázatban nem szerepel, de többen említették az előnyök között a valós beszédhelyzetben történő és a szabad kommunikációt, valamint a csapatmunkát. A szóbeli kommunikáció erős pozitívumként való megjelenése a japán csoportoknál azt is mutatja, mennyire erősen motiválja a távol-keleti hallgatókat egy valódi kommunikációs helyzeteket a középpontba állító módszer. 
A változatos IKT-eszközök használatával elvégezhető feladatok motiválóak voltak, az aktív részvétel mellett sokszor kreatív megoldást igényeltek a nyelvtanulóktól. Ez segített az idegen nyelvi, társas interakciókban gyakran jelentkező gátlást leküzdeni. A kultúraközvetítés hangsúlyos volta gyakorlási lehetőséget biztosított arra is, hogy a hallgatók saját kultúrájukról reflektáljanak. A felméréskor a kultúra mélyebb megismerésének lehetőségét és a valós országismereti kép kialakítását emelték ki mindkét tanulói csoportban (a magyar mellett külön megemlítve saját kultúrájuk megismerését is - vö. Szili 2005, 51). Mindez nem volt könnyü, mert a visszajelzésekben ezek az összetevők (kreativitás szükségessége, társas interakciók magas száma, saját kultúrára való reflexió, a nyelvtudás gyakorlatba való átültetése) nehézségként is megjelentek, azonban e területek fejlesztése hasznos volt.

A magyar anyanyelvű beszélőkkel való interakciót is a pozitívumok közé sorolták. Ez motiváló volt a japán csoportok esetében is, ahol az interakció félig irányított volt: a magyar hallgatók nem léptek ki tanári szerepükből, nem kezdeményeztek az instrukciókon és a visszacsatolásokon túl további személyközi kommunikációt. Ebből a tapasztalatból kiindulva a horvát projektben igyekeztünk ösztönözni az órán kívüli kommunikációt is. Mindkét fél, de elsősorban a nyelvtanulók bátortalansága volt az oka, hogy ez csak nagyon korlátozottan valósult meg. Az oktatói biztatásra felvett kezdeti kapcsolatok nem folytatódtak a magánszférában, csak a feladatmegoldások, illetve -javítások során, bár akkor az interakciók a feltétlenül szükségesnél intenzívebbek/bővebbek voltak.

A magyar hallgatók az IKT-s eszközhasználatuk fejlődését emelték ki, bár mindannyiuk szerint segítette a projekt a jövőbeni MID-tanárrá válásukat is. A projekt az IKK fejlesztését állította középpontba és a nyelvtanulók is ebben látták leginkább saját idegen nyelvi kommunikációs kompetenciájuk fejlödését, ugyanakkor a tanárjelöltek nem ezt említették első helyen. Hasonló projekt tervezésekor érdemes nagyobb hangsúlyt fektetni erre az előkészítő szakaszban, hogy ez a cél a feladatok készítői számára is nyilvánvalóbb legyen, ezáltal ők is tudatosan törekedhetnek saját interkulturális kompetenciájuk fejlesztésére. 


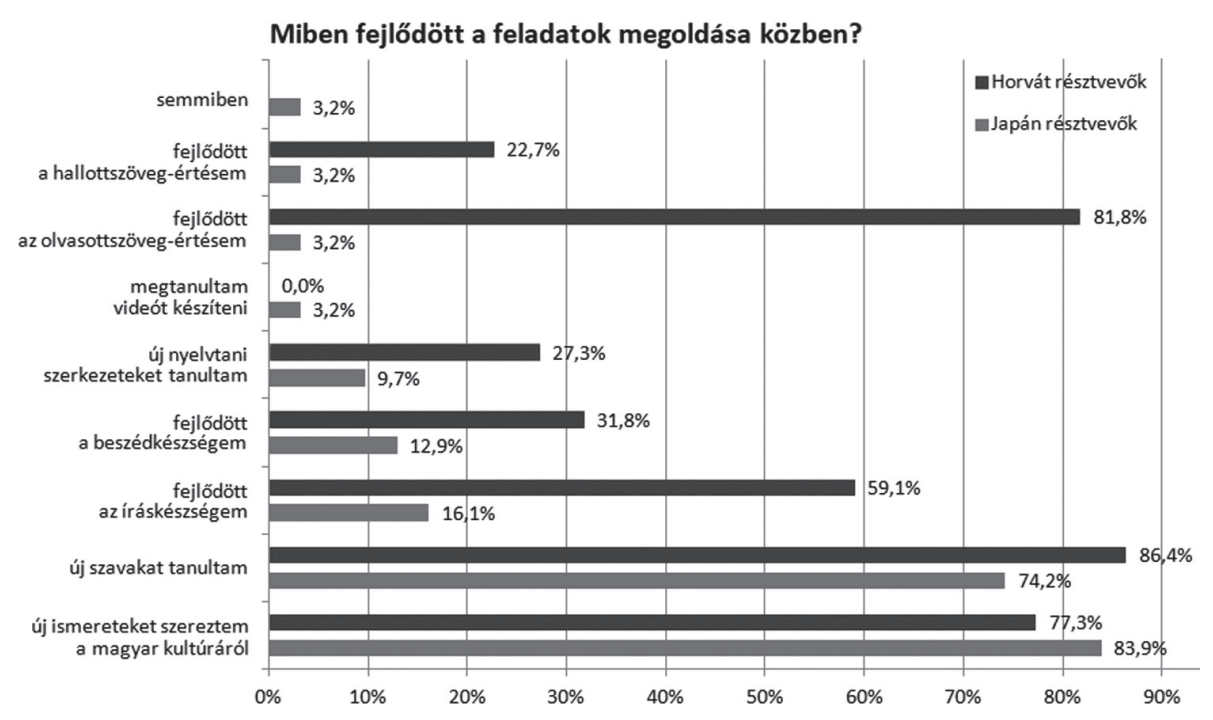

3. ábra. A Miben fejlödött a feladatok megoldása közben? kérdésre adott válaszok

\section{Mi volt nehéz?}

A nyelvtanulók 14, a projekt során nehézséget okozó összetevőt soroltak fel. Meglepő módon a japán diákok több mint felénél szerepelt a technika a felsorolásban. A horvát nyelvtanulók számára a feladatok sok új elemet tartalmazó szókincse jelentette a legtöbb nehézséget, a japánoknál ez a második helyen szerepel. A horvát diákok közül sokan a „hagyományos nyelvtanulás” további két összetevőjét, a nyelvtant és a kiejtést sorolták fel (27,8 \%, illetve 27,8 \%). A kulturális tényezőknek, ezen belül a tanuláshoz való viszonyban meglévő különbségeknek tudható be, hogy ugyanez a két tényező a japán diákok felsorolásában alig fordul elö (3,2 \%, illetve 3,2\%). Viszont közel tizedüknek (9,7\%) okozott nehézséget a feladatok teljesítéséhez szükséges kreativitás hiánya, míg ez a horvátoknál fel sem merült. Ők viszont a projektre fordított időt jelölték meg problémaként (közel negyedük, 22,2\%). Mindezekből is fontos különbségként rajzolódnak ki a két csoport közötti attitüdbeli eltérések.

A horvát hallgatók a feladatok túl magas nyelvi szintjét kisebb arányban tartották nehézségnek, mint japán társaik, azonban az idő vagy a motiváció hiányát, sőt, meglepő módon a szégyenlősséget és az interkulturális nehézségeket is nagyobb részük jelölte meg problémaforrásként a japán résztvevőkhöz 
viszonyítva. Ezek a tényezők részét képezik az IKK attitüd komponensének, így ezek az eredmények is rávilágítanak ezek fejlesztésének jelentőségére a nyelvtanulás folyamatában.

A japán diákoknál ezek alacsonyabb befolyásoló hatását magyarázhatja az interkulturális kommunikációban, illetve az interperszonális helyzetekben megjelenő idegennyelv-használat rendkívül erős motivációs hatása, amelyet Yashima (2002) a nemzetközi beállítottság fogalmával ír le. Az ehhez kapcsolódó attitüd magában foglalja többek között a külföldi és nemzetközi események iránti érdeklődést, a külföldön való tanulás vagy munka iránti hajlandóságot és a nyitottságot a más kultúrák képviselőivel való interakcióra. A japán nyelvtanulók számára az idegennyelv-tanulás sok esetben a (kül)világgal való kapcsolatot szimbolizálja, ami feltételezhetően még hangsúlyosabban van jelen azoknak a nyelvtanulóknak az esetében, akik az angolon kívül más idegen nyelvet is tanulnak (vö. Okamoto 2020). Feltételezhetjük, hogy a nemzetközi beállítottság magas szintjével jellemezhető japán résztvevők számára nagyobb motivációt jelenthetett az interkulturális kapcsolatfelvétel lehetősége, ami segíthetett legyőzni a projekt során felmerülő nehézségeket (pl. a távol-keletiekre jellemző szégyenlősséget). A nemzetközi beállítottság pozitív hatását a kommunikációra való hajlandóságra Yashima, Zenuk-Nishide és Shimizu (2004) az angolt idegen nyelvként tanuló japánoknál statisztikai eszközökkel is kimutatta, és ezt támasztotta alá az itt bemutatott projekt is (vö. Borsos-Kruzslicz 2019).

A tanárjelöltek oldaláról is nehézségként jelentek meg az interkulturális kommunikációs kompetenciához kapcsolódó készségek (például kulturális érzékenység, interkulturális kompetencia). Miközben ők maguk a szakmódszertani ismeretek alkalmazását és a szükséges tudásanyag megszerzését tartották fontosabbnak, az IKK fejlesztésének szükségét (és módszertani szempontból is releváns voltát) mutatta az is, hogy a tanárjelöltek a projektben készített feladatok nehézségeként emelték ki a ,japán diákok eltérő feladatfelfogását”. Szokatlan volt számukra, hogy egy adott instrukció más hatást vált ki a diákokban, mint amelyet az európai nyelvtanulók esetében megszoktak. Hiába tanultak a képzésük során ennek elméletéről, a kulturálisan eltérő kommunikációs stratégiákkal való szembesülés meglepte őket. Már csak ezért is mondható fontosnak a gyakorlati, interkulturális projektek megvalósulása már az idegennyelv-tanári képzésben (vö. Dombi 2017). 


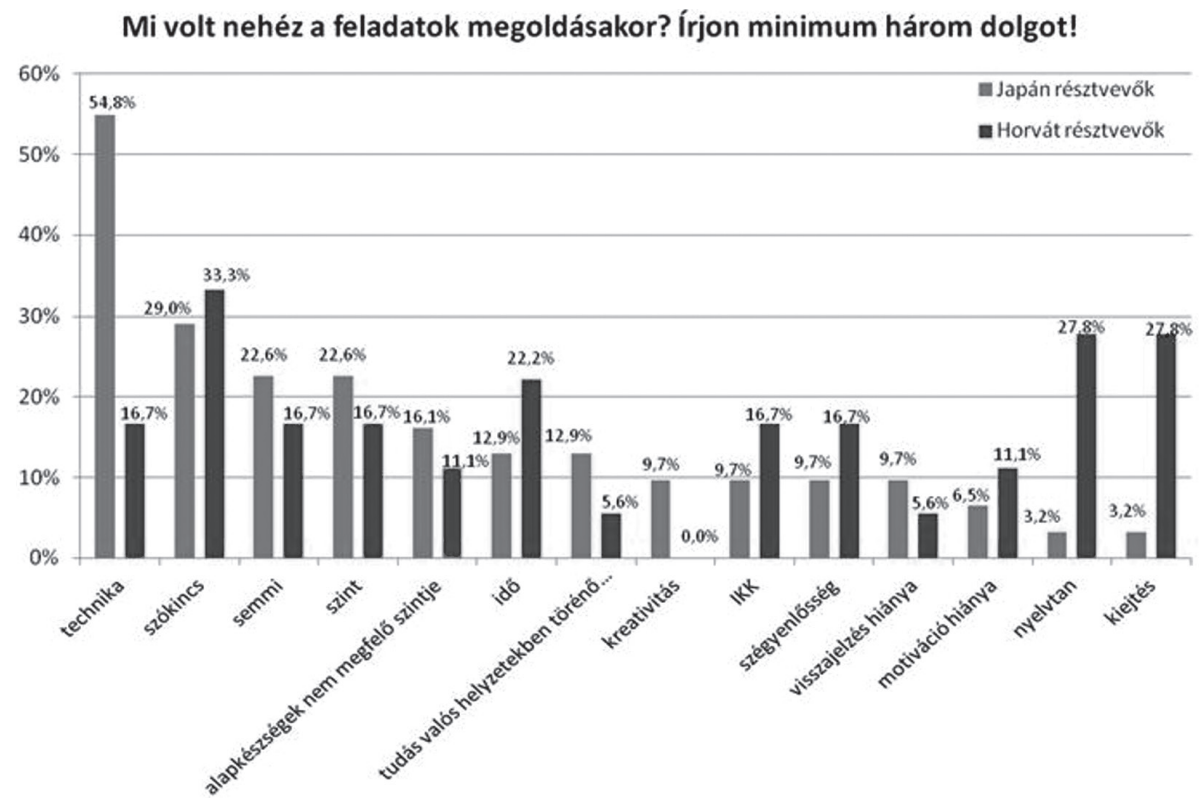

4. ábra. A Mi volt nehéz a feladatok megoldásakor? kérdésre adott válaszok

\section{Feladatokon kívüli kommunikáció a tanárjelöltek és a nyelvtanulók között}

A projekt tervezésekor szempont volt a résztvevők között a feladatokon túlmenő, személyes kommunikáció kialakítása, mivel a nem célnyelvi környezetben tanuló nyelvtanulóknak csak korlátozott lehetőségeik vannak magyar anyanyelvü beszélőkkel kapcsolatba kerülni.

A kérdőívekre adott válaszok szerint ennek ellenére nem alakult ki jelentős személyes kommunikáció a feladatmegoldásokon túlmenően. Ahogyan már a feladatok megoldásának szintjén is problémát jelentett az IKK-hoz kapcsolódó attitüd komponense, ez még inkább meghatározta a személyes kapcsolatfelvétel megvalósulását (bár mindkét projektben több résztvevő is időhiánnyal indokolta ezt). Mind a horvát, mind a japán hallgatók oldaláról felmerül például a félénkség (,nem voltam elég bátor”, „,mert azt gondoltam, hogy senki sem lépett velük kapcsolatba a csoportból”, „,nem tudtam, mit beszéljünk”), szégyenkezés („mert én nem beszélgethetek magyar emberrel, sajnos nem érthetek mindent”). Megemlíthetjük továbbá, hogy több válaszadó azért nem vette fel a kapcsolatot a magyar hallgatókkal, mert még soha nem találkozott velük személyesen (,nem ismerem őket”). 


\section{Összegzés}

Dolgozatunkban egy web 2.0-s projekten keresztül adtunk példát az IKT-eszközök nyújtotta kollaborációs lehetőségekre a magyar mint idegen nyelv oktatásában. A magyar tanárjelöltek és japán, illetve horvát nyelvtanulók kooperációjában zajlott két projektet minden résztvevője hasznosnak ítélte, bár a hangsúlyok eltéröek voltak az egyes csoportokban. A projekt a fó céljaként kijelölt interkulturális kommunikatív kompetenciát minden résztvevő számára sikeresen fejlesztette, egyúttal rávilágított az IKK fejlesztésének jelentőségére az idegennyelv-tanulás folyamatában. A spontán interperszonális kommunikáció mindazonáltal csak kismértékben valósult meg a csoportok közötti kulturális különbség mértékétől függetlenül. Ugyanígy nem a nyelvi készségek fejlődése jelent meg kiemelt területként a hallgatói visszajelzések alapján, viszont általánosan elmondható, hogy a célnyelvi szókincs bővülését nagyban elösegítette a közös munka.

A harmadéves horvát csoport aktivitásának alacsony szintje azt igazolta, hogy a bármily kismértékü tanári közremüködés elengedhetetlen része a sikeres tanulási folyamatnak. A digitális távoktatás fokozott elterjedése kapcsán érdemes szem elött tartani, hogy - mint projektjeink rámutattak - a projektalapú kollaboratív munka a digitális oktatás hatékony formája, mindazonáltal megfelelő eredmények eléréséhez különös figyelmet kell fordítani a tanulmányunkban bemutatott tényezőkre.

\section{Irodalom}

Apple, Matthew T.-Da Silva, Dexter-Fellner, Terr eds. 2013. Language Learning Motivation in Japan. Bristol-Buffalo-Toronto: De Gruyter.

Beneke, Jürgen. 2000. Intercultural competence. In Training the trainers, ed. Bliesener, Ulrich. 108-109. Köln: Carl Duisberg Verlag.

Borsos Levente-Kruzslicz Tamás. 2017. Interkulturális kommunikatív kompetencia fejlesztése IKT eszközökkel. Egy japán-magyar projekt tanulságai. THL2 (1-2): 270-288.

Borsos Levente-Kruzslicz Tamás. 2019. Magyar szakos japán hallgatók interkulturális kommunikatív kompetenciájának fejlesztése IKT-eszközökkel. Gyermeknevelés 7 (1): 91-98.

Byram, Michael. 1997. Teaching and Assessing Intercultural Communicative Competence.

Cleveden: Multilingual Matters. 
Dombi Judit. 2017. „Egyszerre volt érdekes és ijesztő; de azt hiszem, leginkább hihetetlenül izgalmas volt”: Angol szakos egyetemi hallgatók interkulturális élethelyzetekben ('It was interesting and meanwhile scary, but eventually, it was unbelievably exciting'). Modern Nyelvoktatás 23 (1): 17-30.

Ellis, Rod. 2003. Task-based language learning and teaching. Oxford: Oxford University Press.

Európai Parlament-Európai Tanács 2006. 2006/962/EK ajánlás az egész életen át tartó tanuláshoz szükséges kulcskompetenciákról. http://eur-lex.europa.eu/legal-content/ HU/TXT/?uri=URISERV\%3Ac11090 (2017. ápr. 6.)

Holló Dorottya. 2016. Az interkulturalitás helye az angolszakos tanárképzésben - az interdiszciplinaritás kihívásai. In Kutatások és jó gyakorlatok a tanárképzés tudós mühelyeiböl, szerk. Károly Krisztina-Homonnay Zoltán. 178-192. Budapest: ELTE Eötvös Kiadó.

Illés, Éva-Akcan, Sumru. 2017. Bringing real-life language use into EFL classrooms. ELT Journal 71 (1): 3-12.

Innovative Teaching and Learning Research 2011. 21CLD Learning Activity Rubrics. https://education.microsoft.com/GetTrained/ITL-Research (2017. ápr. 6.)

O’Dowd, Robert-Lewis, Tim. 2016. Online Intercultural Exchange: Policy, Pedagogy, Practice. London: Routledge.

OECD 2005. The definition and selection of key competencies. Executive summary. https://www.oecd.org/pisa/35070367.pdf (2020. nov. 15.)

Okamoto, Mari. 2020. A magyar mint főszak a japán felsőoktatásban. In Spectrum Hungarologicum 10, szerk. Karizs Krisztina-Fenyvesi Kristóf-Lahdelma Tuomo, 24-36. Jyväskylä: University of Jyväskylä. https://jyx.jyu.fi/bitstream/handle/ $123456789 / 71262 / 1 /$ Hungarologia_a_tavolkeleten.pdf (2020. nov. 17.)

Orsini-Jones, Marina-Lee, Fiona. 2016. Intercultural Communicative Competence for Global Citizenship. London: Palgrave Macmillan.

Peck, Christiane-Rot Gabrovec, Veronika-Čaňková, Michaela-Lázár, Ildikó-ViefSchmidt, Gerlind. 2007. Materials and activities to develop intercultural competence. In Developing and assessing intercultural communicative competence, eds. Lázár, Ildikó-Huber-Kriegler, Martina-Lussier, Denise-Matei, Gabriela S.-Peck, Christiane. 19-22. Strasbourg: Council of Europe.

Piros Borbála. 2006. Az interkulturális dimenzió bevonása a magyar mint idegen nyelv oktatásába. Hungarológiai Évkönyv (1): 90-96.

Szili Katalin. 2005. A múlt tanításairól és a jelen kihívásairól a nyelv és a kultúra tanításának kapcsán. THL2 1 (1): 44-53.

Van Ek, Jan Ate. 1986. Objectives for Foreign Language Learning. Vol 1: Scope. Strasbourg: Council of Europe

$\mathrm{W} 1$ = https://newzoo.com/insights/rankings/top-50-countries-by-smartphonepenetration-and-users (2020. nov. 15.) 
Yashima, Tomoko. 2002. Willingness to communicate in a second language: The Japanese EFL context. Modern Language Journal 86 (1): 55-66.

Yashima, Tomoko-Zenuk-Nishide, Lori-Shimizu, Kazuaki. 2004. The Influence of Attitudes and Affect on Willingness to Communicate and Second Language Communication. Language Learning 54 (1): 119-152.

\section{COLLABORATIVE ONLINE LANGUAGE LEARNING: POTENTIALS AND LESSONS LEARNT BASED ON TWO HUNGARIAN AS A FOREIGN LANGUAGE PROJECTS

$$
\text { Croatian - Hungarian - Japanese convergences }
$$

The study introduces snippets of a research result related to teaching Hungarian as a foreign language. The participants of the research were Hungarian teacher-trainees, Japanese and Croatian language learners, and it was conducted at the universities of Budapest, Osaka and Osijek. These two projects focused on intercultural communication competency and on the usage of ICT-tools. The interface for communication was provided by social media pages (LINE and Facebook). The topic centred tasks available on both computer and mobile devices were created by the teacher-trainees, and were solved by the language learners either in pairs or in teams. The last element of the projects was a survey completed by the participants. Based on the results of these projects, we elaborated on what was found useful by the participants, moreover what they found challenging. As expected, cultural mediation and real communication were proved to be among the strengths, as well as the practice gained by theusage of ICT-tools. The two student groups indicated the challenges in varied measures. Parallel with other international studies, the results of our research also proved that the teacher being in control is an inevitable element of the projects. However, the teacher being in control can bring a lively colour into language teaching and learning.

Keywords: intercultural communicative competence, Hungarian as a foreign language, postcommunicative language learning, real communication, web 2.0

\section{MOGUĆNOSTI I POUKE KOLABORATIVNE ONLAJN NASTAVE JEZIKA NA OSNOVU DVA ISTRAŽIVAČKA PROJEKTA MAĐARSKOG JEZIKA KAO STRANOG}

\section{Hrvatsko-mađarsko-japanski primer}

Rad prikazuje rezultate jednog istraživanja vezanog za nastavu mađarskog jezika kao stranog. Učesnici projekta su bili budući profesori mađarskog jezika, kao i japanski i hrvatski polaznici kurseva mađarskog jezika na univerzitetima u Budimpešti, Osaki i u Osijeku. U fokusu istraživanja su bili interkulturalna komunikativna kompetencija 
i upotreba IKT sredstava. Komunikativnu platformu su činile društvene mreže (LINE ili Facebook). Tematske zadatke kojima se moglo pristupiti putem računara i telefona izradili su budući profesori, a rešavali su ih polaznici kurseva u paru ili u manjim grupama. Poslednji element projekta je predstavljalo ispunjavanje upitnika od strane učesnika. Na osnovu rezultata upitnika, u radu se svode zaključci o tome šta su učesnici smatrali značajnim, odnosno šta im je zadavalo teškoće. Prema očekivanjima, među pozitivnim stvarima se nalaze širenje kulture, stvarna komunikacija, kao i iskustva stečena u upotrebi IKT sredstava. Dve grupe učenika su u različitoj meri ocenili elemente koji su im stvarali probleme. Slično međunarodnim iskustvima, rezultati ovog istraživanja potvrđuju da je uloga profesora neizostavan element projekta, i može predstavljati uspešan i delotvoran element u nastavi i učenju jezika. Ključne reči: interkulturalna komunikativna kompetencija, mađarski kao strani jezik, postkomunikativna nastava jezika, stvarna komunikacija, web 2.0 